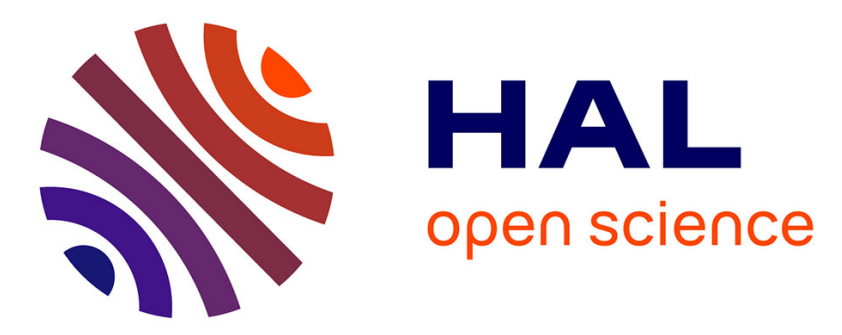

\title{
Coining societies: an inter-functional comparative analysis of the Euro \\ Steffen Roth
}

\section{To cite this version:}

Steffen Roth. Coining societies: an inter-functional comparative analysis of the Euro. Innovation / Innovation: The European Journal of Social Science Research, 2014, 27 (2), pp.99-118. 10.1080/13511610.2013.864229 . hal-01053519

\section{HAL Id: hal-01053519 https://hal.science/hal-01053519}

Submitted on 31 Jul 2014

HAL is a multi-disciplinary open access archive for the deposit and dissemination of scientific research documents, whether they are published or not. The documents may come from teaching and research institutions in France or abroad, or from public or private research centers.
L'archive ouverte pluridisciplinaire HAL, est destinée au dépôt et à la diffusion de documents scientifiques de niveau recherche, publiés ou non, émanant des établissements d'enseignement et de recherche français ou étrangers, des laboratoires publics ou privés. 


\title{
Pre-publication draft of:
}

Roth, S. (2014), Coining societies. An inter-functional comparative analysis of the Euro, Innovation: The European Journal of Social Sciences, DOI: $10.1080 / 13511610.2013 .864229$.

Published version available at: https://steffenroth.files.wordpress.com/2014/07/coining-societies.pdf

\section{Coining Societies. An Inter-Functional Comparative Analysis of the Euro.}

\author{
Steffen Roth \\ Department of Management and Organization, ESC Rennes School of Business, France \\ Department of Sociology, Yerevan State University, Armenia \\ Department of Sociology, University of Geneva, Switzerland
}

\begin{abstract}
The present analysis of the Euro looks for the marks that function systems make on what we commonly take for the European money. Clearly distinguishing between coins and currency, the Euro coins and banknotes are not taken for economic tokens per se, but for storage devices that contain both economic and non-economic information. A systemic analysis of the function system references on these storage devices shows that the economy has left fewer marks on the Euro than politics, art, and the mass media systems have. We hence argue that 'the Euro' 'is' not just money with a political second mission, but rather can be understood as an indicator of the relative relevance that specific function systems do or do not have for the European societies and the European society.
\end{abstract}

Keywords: multi-functional; polyphonic; function system; money; currency; the Euro.

\section{Introduction}

Though functional differentiation is said to dominate the modern world society (Luhmann 1984, 1997; Stichweh 1995), most social research is focussed on more 
intimate forms of differentiation. The most common exercise surely is to group social entities into segments like gender, color, or race, and then to rank these according to scalable characteristics. In this sense, the crossing of certain forms of segmentary differentiation seems to somehow automatically call for certain forms of stratificatory differentiation, or of well-meant efforts of de-stratification, respectively. While we are so much used to arranging income brackets along color lines or to mainstreaming the life-chances of the genders, the question of what function system is more relevant than another seems rather artificial: What if research proved that democracy renders us ill? Would health be higher a value than politics, then? Or would we simply take comfort in the assumption that science is currently not popular enough to advise on a question like this?

Without any doubt, neither science nor any other function system of society could give a final answer to such a question today. However, a brief historical review reminds us of times when things were much clearer, when religion indeed could define what is false or true, who is in power, and how to do business. Times have changed a lot since those days. This is true as long as we leave it at the level of interaction, where we nowadays can appreciate faith and truth, peace and profit, health and beauty, all to the same degree at the same time. However, the more exciting case is when we cannot realize all these options at once, when we are perfectly aware of the fact that we are talking about incommensurable categories and nonetheless feel the need to decide.

One of the most prominent cases of this kind of need for decision concerns the selfdefinition of society as capitalist. As widespread the label is itself, little consensus is, however, on the question of whether we either owe our form of capitalism to the primacy of politics or to the primacy of the economy (Risse 2003; Wallerstein 2003). Increasingly tired of the never-ending competition between politics and the economy, 
slowly but surely we are starting to gaze off into the distance of a 'next society' (Baecker 2007; Drucker 2002), still without having more than a vague intuition of what a post-capitalistic society actually could be: Are we heading for a 'media society' (Croteau and Hoynes 2003; Dennis 1978; Eaman 1987), and if, would it resemble the network society Manuel Castells (1996) heralds, or rather Noam Chomsky's propaganda society? Do we rather have to expect the transformation to a knowledge society (Boehme and Stehr, 1986) mainly focused on science and education? Is it the dawn of a wellness society centred on physical and spiritual health? Is god returning to the throne?

Indeed present society has room for all these societies: Isn't society a muse that inspires the most different self-portraits? Isn't it all about diversity, the peaceful coexistence of genders, colors and most recently also about function systems today?

It is indeed, as long as there is enough time and space for linking endless chains of communication, which is a true picture if we are referring to society as a whole. However, in doing so, we do not get the full picture at all. Rather, we get white noise that only makes sense if we make sense out of it, i.e. if we focus on certain pixels on the entire screen and fade out others, and thereby never forget that our analyses themselves are pixels on the screen we observe.

In this paper, we are using social systems theory to zoom in and enlarge a research field that is small enough to represent a shortage of time and space for communication and therefore indicates a veritable need for decision. In this sense, we followed the idea that "the best way to get into the habit of thinking outside the box is to make sure your box is very, very small" (Jones and Surman 2002, 187). At the same time, the field is chosen carefully enough to ensure that this very shortage is not misunderstood as a form of scarcity that immediately calls for the economy to enter the center stage. In brief we 
are talking about the Euro as a token for the need to decide on which function systems can or cannot be represented on the small space of a coin or a banknote and, thus, consider both media indicators for the relative value of the function systems of both European societies and the European society. Such taking the Euro coins and banknotes as functional approaches to the problem of European collective identities (Schlesinger 1999; Ivic and Lakicevic 2011), we clearly distinguish between coin and currency, between bill and book value. Hence, by searching for the marks that non-economic function systems make on what we commonly take for money, we refer neither to the earmarking of money (Zelizer 1997) nor to "Money as Mass Communication (Lauer 2008), but rather to money as one function among others coins or bills can have.

\section{A 'functional' approach to the Euro}

Although the European Central Bank (ECB 2010a, 2010b) provides comprehensive information on the appearance of all coins and bills, the bank does not seem to have an analytical interest in the various meanings the Euro carries: The majority of the ECB's scientific publications (ECB 2011b) is oriented to its monetary policy rather than to its money'. Even the few design-oriented publications of the ECB or the European National Banks mainly focus on the technical dimensions of design (de Heij and van den Kommer 2008; ECB 2011a). This is also reflected by the fact that the design of the new banknotes was tested for acceptance by a marketing research company only after the decision on the 'design theme', i.e. the symbolic meaning the design is to carry, had already been taken by an expert jury (ECB 2011a, 18). What is more, the public was also not involved in the majority of selections of themes for the national sides of the coins, though there were exceptions like Italy, where the "the coins were pre-selected by a Technical and Artistic Committee, on the basis of detailed discussions fuelled by opinion polls. The final choice was made in February 1998 by the television viewers of 
RAI uno during a special Sunday broadcast" (EC 2000, 12). However, apart from a few anecdotes like this, the official literature on the introduction of the European currency is rather on anti-counterfeiting measures, on techniques for increasing the Euro's userfriendliness, on logistical challenges, and, last but not least, on the 'Cost of Cash' (de Heij 2010a, 2010b; de Heij and van den Kommer 2008).

A certain fascination for the technical dimension of money can also be observed in the social sciences. Sometimes, it is not only currency designers and a few numismatists that are interested in discussing the mere magnitude of coins: Social psychologists obviously can add their two cents on the correlation between the size and "The Perceived Value of a New Coin" (Boustead 1992), as well. However, most social research on money is focused on either the social footprint of the exchange medium or on the symbolic meaning of what is printed on it.

If we now conduct a 'functional' iconographical analysis of the Euro, we start with the modest assumption that the functional differentiation of society must have left its mark on coins and banknotes, as well. This approach is new insofar as references to function systems on 'money' have indeed been noted, but they have not been studied with a systematical interest in both their presence and their absence, and therefore have been presented with a pronounced bias, so far. The reason for this bias is probably the obvious: There is plenty of evidence for the presence of politics on coins and banknotes from all over the world. Referring to this common-place that goes without citing, the Euro can easily be taken for both the maker of a European economic area and the marker of a palliative political convergence culminating in something like a European collective identity (Fornäs 2008; Hymans 2004; Zäch 2005). Accordingly, the European currency has also been studied as an example of 'banal nationalism' (Billig 1995), i.e. an omnipresent, inconspicuous, and therefore powerful political messenger who is 
carrying its ideology to every corner of Europe (Raento et al. 2004). In this sense, it is assumed that "(m)oney has two functions as daily means of exchange used by everyone on one side and as official documents of state representation on the other side" (Zäch 2005, 1429). While other functions could be added at discretion, most iconographies leave it at the spot on this already well-illuminated politico-economic double star. They do so even if sets of categories as different as "(1) human figures; (2) cultural patrimony; (3) state heraldry; (4) artifacts; (5) nature; and (6) text" smoothly "emerge" on the maps of a 'political geography' of the Euro coins (Raento et al. 2004, 933; cf. also Foucault 1970, xvi). After they passed the initial check for gender imbalances, the human figures are again interviewed for their "social or political" relevance (Raento et al. 2004, 937ff). The few left-overs, namely art and religion, are quickly assigned to yet another container category: culture, which then also acts as - political - symbol of the European nation of culture or one of its nations. No need to say that state heraldry is all about politics, just as most of the inscriptions and even the best part of nature are. In the end, the "euro coin imagery" evolves “(a)s any political iconography” (ibid, 952).

Accordingly, research on changes of value dimensions in the European currency iconography (Hymans 2004, 10) also ends up in cross-tabbing traditional, materialist and post-materialist milieus with states, "society/classes" and individuals. The typology of "possible iconographic choices" produced in such way inevitably does not leave the realm of politics and finally paves the way to a loud and overt discussion on whether or not the European currency iconography indicates the emergence of a "European 'Demos'” (23).

By no means do we want to hide the fact that all mentioned studies are meritorious insofar as they detected on the coins and banknotes the most different echoes of segmentary, stratificatory, and maybe further forms of differentiation. However, if it 
comes to functional differentiation, then their Euro most often is all about politics and the economy, although there is plenty of evidence for more exotic functions: As for "Art and Money" (Shell 1995), there is enough art in money to allow for rewriting music history based on numismatics (Marian-Bälasa 2003; Vorreiter 1975). Ancient money also contains highly specific medical information (Nemes 2002). Money sends religious signals (Wasserstein 1993; Priddat 2003), which is often ignored and sometimes even object of non-observance, e.g. if Zäch points out that "it is striking that apart from images of churches (Santiago de Compostela, Dome of St. Stephan) no religious themes seem to be evoked" $(2005,1432)$ on the Euro, which might be true if one's mission is “(t)o study national representation by coin images" $(2005,1433)$, but not if we consider the Greek $2 €$-coin (by which Greece reminds the Occident of its pagan roots), some of the Maltese, San Marinese, and, finally, all of the Vatican coins ${ }^{1}$.

The issue with a 'functional' iconography of the Euro is therefore less about running counter to standard iconographical research interests. Rather, the problem is that standard iconographies tend to pre-adapt the observation of functional references to their research interests, which then are mostly in line with the politico-economic common sense that money is an economic institution sanctioned by politics (Marazzi 2004; Papadopoulos 2009) and that collective identities are essentially a problem of political structures and economic positions (cf. the criticism of [Poche 1997]). In the present article, however, we will draw on Niklas Luhmann's theory of social differentiation in general and his concept of functional differentiation in particular (Luhmann 1977; Luhmann and Barrett, 2012) in order to challenge this biased attention to political and economic tokens. In concrete terms, we will show that nearly the entire

\footnotetext{
${ }^{1}$ We need to non-observe even more before we can claim that the Euro were "Money for Mars" (Zakaria 1999), i.e. a meaningless iconography, which is not true even for the deliberately 'neutral' banknote themes (ECB 2011a).
} 
set of Euro coins and banknotes is laced with marks that serve as references not only to the political system and the economy, but also that there is science, art, religion, education, sports etc. on the Euro, as well. Hence, if we ask the right questions to the Euro, then it will tell a story about both the absolute relevance of functional differentiation and the relative relevance of the individual function systems in the European societies.

\section{The Euro as dissemination medium and storage device}

The quest for the function system references of the Euro may be much more contraintuitive an endeavor than looking for plants, animals, landscapes and humans, and class and gender imbalances. Nonetheless, the highly visible presence of the function systems economy and politics on coins and banknotes calls for the question of presence or absence of the other function systems of the society. Such an approach is, however, not only hindered by preferences for specific forms of differentiation and function systems, but also by common senses on money itself. Reviewing the discussion on the political dimension of money, we are struck by statements like: "Money has two functions as daily means of exchange used by everyone on one side and as official documents of state representation on the other side" (Zäch 2005, 1429), or by the idea of money as a powerful political messenger (Raento et al. 2004). If "( $\mathrm{t}$ )he modern economic system has its unity in money" (Luhmann 1995c, 461), then how can the economic exchange medium money act as a political representative or messenger?

The truth is: It cannot. If we are talking about money, then we are talking about the economy, and about nothing but the economy (cf. Luhmann 1988, 14ff). This definition does not exclude any attempts to observe 'social meanings of money' (Zelizer 1997): While we think that the notion 'social meanings' is not too well-chosen because it denies the very social character of money that it claims to add, we perfectly agree with 
the idea of studying how politics, religion, or science can be 'irritated' by money. However, just as a photograph is not a true mirror to the photo scene (cf. Warren 2002), just as the footprint is not the foot, the impact that money has on the non-economic realm is not economic, at all.

The analysis of the non-economic meanings of money and its manifold relationships to society (Carruthers 2005a, 2005b, 2010; Cooper 2009; Ingham 2001; Lapavitsas 2005; Zelizer 1997) surely is a most interesting field. However, we are interested in the specificity of money (Ingham 2007) only as much as it takes to distinguish money from power or truth and further symbolically generalized communication media of the function systems of society. In doing so, we do not refer to "Money as Mass Communication" (Lauer 2008), but rather to money as only one of many functions that a coin or banknote can have ${ }^{2}$.

In other words: Just as a piece of gold is not positively money (Foucault 1970, 189ff), neither coins nor banknotes essentially are the economic means of exchange they can be taken for. We therefore clearly distinguish between the Euro money and the Euro coins or banknotes and, hence, claim that it is the coins and banknotes (and not the money) that serve as dissemination media. In this sense, we consider the set of Euro coins and banknotes as storage devices for tokens that refer not only to economic and political, but also to scientific, religious, artistic, or educational information. Against this background, we may find that only few coins and banknotes show nothing but economic marks ${ }^{3}$. In this sense, the present paper is on what is on 'money' other than

\footnotetext{
${ }^{2}$ In a different context, we might also find that an artwork can also be considered an investment or store of value.

${ }^{3}$ At least in their pictographic dimension, the French 1 centimes (1968) and the Italian 10 Lire (1989) pieces are examples for coins containing only economic information: Both show agricultural symbols. While the Italian coin display both a plough and an ear (and therefore, at an inter-textual level, maybe also an educational dimension), the French coin shows nothing but
} 
money. Sometimes, this is money again: The Greek $1 €$-Coin displays an Ancient Tetradrachm, i.e. it represents a re-entry of either coin or money, which is quite a difference to conventional economic icons, or to representations of politics, religion, or art. In the following, the challenge will be to show not the invisible function systems and their invisible symbolically generalized media of communication (Esposito 2006), but the marks they make on the Euro coins and banknotes. In a first step, we therefore assume that society cannot only be differentiated in terms of a) homogenous and equal segments, b) homogenous and unequal centers and peripheries, and c) heterogeneous and unequal strata, but in terms of d) heterogeneous and equal function systems (Luhmann 1995c, 190f, 1997, 609ff; cf. also [Andersen 2003]).

Function systems differentiate society according to the function they fulfill for it, which they do by binary re-coding communication according to a specific symbolically generalized communication medium (Luhmann 1995, 161). In doing so, each function system applies only one single code, which it also applies exclusively. In this sense, science, and only science, is all about programs that define what is truth, binary coded as true or untrue. The medium of science therefore is truth, while the function of science is to provide society with ongoing knowledge communication (cf. Table 1).

Table 1: The Function Systems of Society

\begin{tabular}{|l|l|l|l|l|}
\hline System & Code & Medium & Program & Function \\
\hline Policy & Inferior/Superior & Power & Ideology & Control \\
\hline Economy & Non-/Payment & Money & Price & Distribution \\
\hline Science & Un-/True & Truth & Theory & Knowledge \\
\hline Art $^{4}$ & Imitation/Innovation & Taste & Style & Creation \\
\hline Religion & Immanent/Transcendent & Belief & Confession & Revelation \\
\hline
\end{tabular}

an ear. In any case, both specimens indicate that coins do not positively display political icons (still, both Republics are set out in writing, of course).

${ }^{4} \mathrm{We}$ argue that the function of art is not to discuss or produce artworks. Rather, we assume the distinction is not only of innovation and chance, nature, or imitation (Luhmann, 1997, 978f, 1995b, 2000a), but also in the sense, which Pierre Bourdieu's "Distinctions" (1984) reminds us of. 


\begin{tabular}{|c|c|c|c|c|}
\hline Legal System & Wrong/Right & Norm & Law & Trust \\
\hline Health System $^{5}$ & Sane/Insane & Illness & Diagnosis & Therapy \\
\hline Sport $^{6}$ & Failure/Success & Achievement & Goal & Performance \\
\hline Education ${ }^{7}$ & Un-/Placeable & Career & Test & Placement \\
\hline Mass Media $^{8}$ & Non-/Informative & Record & Topic & Reproduction \\
\hline
\end{tabular}

The question of what and how many function systems actually do exist it is still up for discussion. In the following, we assume the existence of ten function systems ${ }^{9}$ : politics, the economy, science, art, religion, the legal system, the health system, sports, education, and the mass media system.

Table 1 resembles the compilations of function systems proposed by Jan Künzler (1987, 1989), Werner Reese-Schäfer (1999, 2007), or Niels Akerstroem Andersen

${ }^{5}$ The program of the health system (cf. Luhmann 1990a) is not, as proposed, the Hippocratic oath. Rather, diagnoses define what is sane or insane. The health systems' medium is illness (Baraldi, Corsi and Esposito 1999, 116), not treatment, or therapy. Therapy, not health care, is the function of a system that only works if there is enough diagnoses of illness and, therefore, reason enough for therapy communication.

${ }^{6}$ Sport does not appear in the list of function systems proposed by Werner Reese-Schäfer (2007, 120; cf. also [Baraldi, Corsi and Esposito 1999]). However, in view of recent works (Bette 1999; Cachay and Thiel 2000), we consider sport a function system. In doing so, we do not have the special case of competitive sport in mind, but rather sport in general. As a medium of sport, we propose achievement, while a certain goal defines what is success or failure. The social function of the system is performance communication.

${ }^{7}$ An achievement placed within the context of others makes education. In fact, the function of education is placement by means of tests that fathom what or who is placeable within a given context. Placeable/un-placeable, therefore, is the code of education (Luhmann 2001, 59, 73), while the carrier is its medium. In this sense, competition (cf. the French concours) is a form of education, not a characteristic of sport.

8 The function of the mass media system (Luhmann 1996, 2000c) is the cross-social construction of the reality (Luhmann 1997, 591f), i.e. its self-definition. While the topic defines what is information or non-information, the record(ing) is the medium of the mass media system.

${ }^{9}$ This means that we abandon controversial candidates for the function system status such as love, ethics, or social work (Baecker 1994; Fuchs 2000; Maass 2009; Reese-Schäfer 1999, 2007). Especially in the third case, our claim for the exclusion is strong: We perceive social work as a sub-function of the health system: Social work takes effect when a 'social pathology' is diagnosed; its function clearly is 'social therapy'. If we nonetheless took social work for a function system, then psychology ('psychotherapy') also deserved the same status. In the end there were three different function systems each devoted to - physical, psychic and social therapy, which makes as much sense as claiming a need for three different function systems dealing with the distribution of physical, psychic and social goods, thus splitting the economy into three. Further ideas like the call for the inclusion of 'the psychic system' (Reese-Schäfer $1999,2007)$ into the list of function systems of the society are out of question. 
(2003). However, our suggestion significantly deviates from the samples (cf. footnotes $3-7)$.

With particular regard to the function of the mass media system, we can now get back to the idea that a coin or banknote represents a form of dissemination medium:

\begin{abstract}
"The basic idea is that only the machine production of a product as carrier of the communication - but not yet writing as such - gave rise to the differentiation of a specific system of the mass media. In a certain way, the dissemination technology substitutes the effect that money has as a medium of the differentiation of the economy: For its own part, it only constitutes a medium that allows for forms, which, unlike the medium itself, can then shape the communicative operations that allow for the differentiation and the autopoietic closure of the system". ${ }^{10}$
\end{abstract}

In this sense, we claim that a coin 'is' not just a token for the economy, but can also be read like a booklet, which is even more so if we recall that banknotes just like books are children of the press and printing age. Accordingly, we are now interested in what function systems are minted and printed on Euro coins and banknotes and, hence, recorded as relevant information. In doing so, we take the presence or absence of a certain function system for a token for a decision concerning its relevance for the selfdefinition of the European societies and the European Society.

\title{
Function systems recorded on the Euro
}

Decoding the symbolic meaning of icons minted or printed on what we commonly take for our currency comes with certain challenges related to the general complexity of symbolic references (cf. Hymans 2004, 18). We therefore do not only trust what we

${ }^{10}$ In original German: "Der Grundgedanke ist, daß erst die maschinelle Herstellung eines Produktes als Träger der Kommunikation - aber nicht schon Schrift als solche - zur Ausdifferenzierung eines besonderen Systems der Massenmedien geführt hat. Die Verbreitungstechnologie vertritt hier gleichsam das, was für die Ausdifferenzierung der Wirtschaft durch das Medium Geld geleistet wird: Sie konstituiert selber nur ein Medium, das Formenbildungen ermöglicht, die dann, anders als das Medium selbst, die kommunikativen Operationen bilden, die die Ausdifferenzierung und die operative Schließung des Systems ermöglichen" (Luhmann 1997, 591f). 
perceive to be appearance, but also rely on official descriptions of design themes (ECB 2010a; ECB 2010b). Hence, we focus on what function system references we find in the official reader instructions exhaustively cited in the appendix (Tables A). However, these instructions do not cover all elements on the specimens, which is most striking with regard to the European stars that are on the border of the reverse (the so-called 'national sides') of the Euro coins. We therefore added short descriptions of further design elements not mentioned by the ECB. Each design element was treated as nominal data, i.e. we did not take into account their size or their position on the coin or banknote. In the same way, we neither counted any frequency of occurrence on the individual specimen nor asked to which extent the façade of the cathedral of Santiago de Compostela (Spanish 1-5 cent coins) refers to religion or to art, respectively. In rare cases like these, we opted for both religion and art.

First, we counted the mere non-/occurrence of function system references a) on all national sides of the Euro coin sets, b) on the common side of the Euro coins and c) on both sides of the Euro banknotes (cf. annex, tables C3 and R3) ${ }^{11}$. Secondly, we then weighted the system references to the (pro rata) share of both the cash and the ordinal

${ }^{11}$ As a matter of course, this approach can be criticized especially with regard to the national side of the Euro coins, where it would make perfect sense to distinguish between the default ring of stars and the 'national field' in the center of the coin, with only the latter being the area that the individual nations were free to design. The ring of stars could therefore be taken as a supranational window with a view to the individual states. With the ring obviously being a political symbol, it definitely would be relevant to note whether or not politics is more than just a default mode of the national side and also appears as a form of national self-definition. However, quite a number of member states is not that particular about the distinction between supranational and national content anyway: Belgium smuggled the King's monogram, the Netherlands the Queen's name and Slovenia the name of its country into the ring of stars, while France generously extended its national design up to the edge of the coins. Activities like these recently induced new design guidelines issued by the European Commission concerning the inviolability of the supranational ring: "The national side of the euro coins intended for circulation should bear the 12 European stars that should fully surround the national design, including the year mark and the indication of the issuing Member State's name. The European stars should be depicted as on the European flag" (EC 2008). 
rank values of the coins or banknotes on which they occurred (cf. annex, tables C1, R1, $\mathrm{C} 2$ and $\mathrm{R} 2$ ).

For the Euro banknotes, we note politics, the economy, art, the legal system, and the mass media system on the front; and politics, the economy, art and the mass media system on the reverse (cf. appendix, table A1). All common sides of the Euro coins refer to politics and the economy (cf. appendix, table A2). The system references of the national sides are presented in table 2, while a detailed statement for the proposed classification is given in the annex (cf. tables B1-20).

First, we started with calculating the share of the cash value that each function system accounts for (cf. annex, table R1). In the Estonian case, for instance, the national side of all coins contains nothing but political symbols. Hence, politics took it all ${ }^{12}$, while in the French case it had to share loot with $\operatorname{art}^{13}$ and the mass media system ${ }^{14}$. In total, a sum of $€ 962.60$ was played, of which politics received $€ 236.38$ (24.6\%), the economy $€ 219.98(22.9 \%)$, the mass media system $€ 211.32(22 \%)$ and art $€ 205.38$ $(21.3 \%)$. The legal system follows with a considerably lower amount of $€ 88.50(9.2 \%)$. Religion received a negligible share of $€ 1(<0.1 \%)$, science, education and sport gained just one cent $(<0.01 \%)$. Health did not score at all.

Table 2. The function system reference of the national sides of Euro coins

${ }^{12}$ Totaling $€ 1.94$ for the entire share of the national side, i.e. $50 \%$ of the case value of a national set of coins.

${ }^{13}$ The initials of their designer, sculptors, or engravers adorn the French, Greece, Italian, Luxembourgian, Maltese, Portuguese, San Marinese, Slovak, and Vatican national sides.

14 The Belgian, Finnish, French, German, Greek, Italian, Luxembourgian, Maltese, Monegasque, Dutch, Portuguese, San Marinese, Slovakian, Slovenian, Spanish and Vatican Euro national sides carry mintmarks and thus recall that coins are in a certain way printed like books. Just like publishing houses, mints and their marks therefore clearly refer to the mass media system. The mintmarks on the Monegasque, San Marinese, and the Vatican coins indicate that these coins are minted in France or Italy, respectively. In these special cases, the mark also indicates that minting is not a form of expression of political sovereignty. This also applies to Slovenia, which is a country with the right to mint but whose coins nonetheless used to be minted in Finland and now are produced in the Netherlands. 


\begin{tabular}{|c|c|c|c|c|c|c|c|c|}
\hline & \multicolumn{8}{|c|}{ Coinage (€) } \\
\hline & 0.01 & 0.02 & 0.05 & 0.1 & 0.2 & 0.5 & 1 & 2 \\
\hline AUS & 1,2 & 1,2 & 1,2 & $1,2,4,5$ & $1,2,4$ & $1,2,4$ & $1,2,4$ & 1,2 \\
\hline BEL & 1,10 & 1,10 & 1,10 & 1,10 & 1,10 & 1,10 & 1,10 & 1,10 \\
\hline CYP & 1,99 & 1,99 & 1,99 & 1,2 & 1,2 & 1,2 & 1,4 & 1,4 \\
\hline EST & 1 & 1 & 1 & 1 & 1 & 1 & 1 & 1 \\
\hline FIN & 1,10 & 1,10 & 1,10 & 1,10 & 1,10 & 1,10 & 1,10 & $1,10,99$ \\
\hline FRA & $1,4,10$ & $1,4,10$ & $1,4,10$ & $1,4,10$ & $1,4,10$ & $1,4,10$ & $1,4,10$ & $1,4,10$ \\
\hline GER & 1,10 & 1,10 & 1,10 & 1,10 & 1,10 & 1,10 & 1,10 & 1,10 \\
\hline GRE & $1,2,4,10$ & $1,2,4,10$ & $1,2,4,10$ & $1,2,3,4,9,10$ & $1,2,4,10$ & $1,2,4,10$ & $1,2,4,10$ & $1,2,4,5,10$ \\
\hline IRE & 1 & 1 & 1 & 1 & 1 & 1 & 1 & 1 \\
\hline ITA & $1,4,10,99$ & $1,4,10$ & $1,4,8,10$ & $1,4,10$ & $1,4,10$ & $1,4,10$ & $1,4,10$ & $1,4,10$ \\
\hline LUX & $1,4,10$ & $1,4,10$ & $1,4,10$ & $1,4,10$ & $1,4,10$ & $1,4,10$ & $1,4,10$ & $1,4,10$ \\
\hline MAL & $1,4,5,10$ & $1,4,5,10$ & $1,4,5,10$ & 1,10 & 1,10 & 1,10 & 1,10 & 1,10 \\
\hline MON & 1,10 & 1,10 & 1,10 & 1,10 & 1,10 & 1,10 & 1,10 & 1,10 \\
\hline NET & 1,10 & 1,10 & 1,10 & 1,10 & 1,10 & 1,10 & 1,10 & 1,10 \\
\hline POR & $1,4,10$ & $1,4,10$ & $1,4,10$ & $1,4,10$ & $1,4,10$ & $1,4,10$ & $1,4,10$ & $1,4,10$ \\
\hline SMA & $1,4,10$ & $1,4,10$ & $1,4,10$ & $1,4,5,10$ & $1,4,5,10$ & $1,4,10$ & $1,4,10$ & $1,4,10$ \\
\hline SLK & $1,4,10$ & $1,4,10$ & $1,4,10$ & $1,4,10$ & $1,4,10$ & $1,4,10$ & $1,4,10$ & $1,4,10$ \\
\hline SLV & $1,10,99$ & 1,10 & $1,2,10$ & $1,4,10$ & 1,10 & 1,10 & 1,10 & $1,4,5,10$ \\
\hline SPA & $1,4,5,10$ & $1,4,5,10$ & $1,4,5,10$ & $1,4,10$ & $1,4,10$ & $1,4,10$ & 1,10 & 1,10 \\
\hline VAT & $1,4,5,10$ & $1,4,5,10$ & $1,4,5,10$ & $1,4,5,10$ & $1,4,5,10$ & $1,4,5,10$ & $1,4,5,10$ & $1,4,5,10$ \\
\hline
\end{tabular}

Though quite good a basis for advanced statistics ${ }^{15}$, the cash value approach to the relative value of the function systems does not make too much sense. We cannot seriously assume that the decision makers wanted to express that a symbol chosen for the $€ 500$ note is $50^{\prime} 000$ times more relevant than the one chosen for the 1 cent coin. However, we can assume that symbols chosen for the $€ 500$ note are perceived to be more relevant than the ones printed on the $€ 200$, etc. We therefore investigated not only the unweighted (cf. annex, table R3) but also the weighted ${ }^{16}$ distribution of function

${ }^{15}$ In fact, it would be nice to have correlations between the cash value of the function systems and the role they play in the national budgets, for example (cf. annex, table R1; country specific breakdown available in table $\mathrm{C} 1$ ).

${ }^{16}$ The Euro is divided into 15 face values. Accordingly, we awarded 1-8 rank points for a function system reference on a coin between $€ 0.01$ and $€ 2$. This accounts 36 point per national side of the coin set. In total, we gave 20 times 36 points for the decisions on the national sides and one times 36 points for the decision on the common sides of the Euro coins. As to the banknotes, two times 9-15 points were given for the front and the back of all notes between $€ 5$ and $€ 500$. In addition, the rank points were assigned pro rata, if need be, i.e. in cases where a 
system references (cf. annex, table R2). In this sense, we acknowledged that both the mere occurrence of a function system and the prestige of the coin on which the system occurs is a most relevant piece of information.

\section{The distribution of function systems on the Euro}

In analyzing the unweighted occurrence of functions systems (cf. annex, table R3), the most interesting finding certainly is that there is no side of any Euro coin or banknote which does not refer to any function system, at all ${ }^{17}$. At the same time, there is only one function system not appearing on at least one coin or banknote: health.

In total, we counted 422 symbols of which 416 had references to function systems and six had symbols that could not be assigned. This result indicates either our fantasy or the relevance of the concept of functional differentiation in general. The amount of system references per country ranges from 7 (Greece) to 1 (Estonia and Ireland) ${ }^{18}$. The function system specific share of occurrences on both coin and banknote sides reads as follows (cf. table 3 ).

Politics is in the lead with $36.3 \%$ of the overall share of decisions and followed by the mass media system with about $29.5 \%$. Art is next, the economy only fourth, and the small percentage of religious symbols indicates that the Christian West is rather on the edge of the Euro, or rather of the Euro cent ${ }^{19}$. The legal system is the last system with a more or less considerable share of around $1 \%$, which it owes only to a copyright sign on the front of the Euro banknotes.

multitude of symbols shared one coin side. In total, 840 points were allocated to the function systems as well as to the 'none' category (cf. annex, table R2).

${ }^{17}$ On a total of six sides out of 182 (cf. annex, table R3) we found design elements not referring to a function system, namely the Cypriote mufflons (€0.01-0.05), the Finnish cloudberries $(€ 2)$ and the Slovene stork (€0.01), which are flanked by political or mass medial symbols.

${ }^{18}$ For further country-specific data cf. annex, table C3.

${ }^{19}$ The disproportionately low score in the cash value ranking clearly indicates that religion is principally found on the low face value specimens. 
Still, the peculiar fourth rank of the Economy makes us think because mintmarks etc. do not occur as often as face values, which actually are on each and any common side of the coins while the mass media system obviously is only on some of the national sides. However, as we took the occurrence of design elements as tokens for decisions, we had to treat the decisions on the design of the common side as just one set of decisions among 21; and in this sense, the decision makers indeed opted more often for a mintmark ${ }^{20}$ or an artistic symbol ${ }^{21}$ than for an economic token, which is only on a limited number of icons, primarily in the form of the values on the Austrian and Greek national $\operatorname{sides}^{22}$. What is more, recent design recommendations of the European Commission ask all member states for a mintmark on each their national sides.

Table 3. Final rankings of the function systems (all coin and banknote sides).

\begin{tabular}{|c|c|c|c|c|c|}
\hline \multicolumn{6}{|c|}{ Share of Function System (\%) } \\
\hline \multicolumn{2}{|r|}{ Cash Value Decisions } & \multicolumn{2}{|r|}{ Weighted Decisions } & \multicolumn{2}{|r|}{ Unweighted Decisions } \\
\hline 1 & Politics (24.6) & 1 & Politics (43.5) & 1 & Politics (36.3) \\
\hline 2 & Economy (22.9) & 2 & Mass Media (28.9) & 2 & Mass Media (29.5) \\
\hline 3 & Mass Media (22.0) & 3 & Art (15.9) & 3 & $\operatorname{Art}(20.7)$ \\
\hline 4 & $\operatorname{Art}(21.3)$ & 4 & Economy $(8.1)$ & 4 & Economy (6.8) \\
\hline 5 & Legal System (9.2) & 5 & Religion (2.3) & 5 & Religion (4.4) \\
\hline 6 & Religion (0.1) & 6 & Legal System (1.0) & 6 & Legal System (1.5) \\
\hline 7 & Science $(<0.1)$ & 7 & Education $(<0.1)$ & 7 & Sport $(0.2)$ \\
\hline & Education $(<0.1)$ & 8 & Science $(<0.1)$ & & Science (0.2) \\
\hline & Sport $(<0.1)$ & & Sport $(<0.1)$ & & Education (0.2) \\
\hline 10 & Health (0.0) & 10 & Health $(0.0)$ & 10 & Health (0.0) \\
\hline
\end{tabular}

${ }^{20}$ Which can be found on 16 out of 20, namely the Belgian, Finnish, French, German, Greek, Italian, Luxembourgian, Maltese, Monegasque, Dutch, Portuguese, San Marinese, Slovakian, Slovenian, Spanish, and Vatican, national sides.

21 In addition initials of the designer, sculptor or engraver French, Greece, Italian, Luxembourgian, Maltese, Portuguese, San Marinese, Slovak and Vatican national sides

${ }^{22}$ Without any doubt, we could argue that the set of national sides indeed is just one set of many, but at the same time, it is also by far the most widespread one. However, starting this kind of calculation meant ending up with taking into account the numbers of coins in circulation, which differ quiet significantly within and between the individual country sets (e.g., the Netherlands do hardly use coins with a value smaller than 5 cent). In this respect, our approach of focusing on decision situation turned out as a good decision, too. 
At least in terms of cash value, economy ranks second due to the fact that it is present on both sides of all banknotes. In the case of politics, the contrast between the low cash value and the high performance in the other rankings also indicates that the function system owes its prominence to its omnipresence rather than to presence on prominent specimens, which would be rather true for art and, to a much lesser extend, for the basically marginal legal system.

Overviewing particularly the national side of the Euro coins (cf. table 4), we find that the economy falls even further behind and is overtaken by religion.

Only 19 out of 422 function system references are made to the economy, most subtle example undoubtedly being the Greek $1 €$ coin with the picture of a coin minted on it. Again, politics leads with a $38.5 \%$ of the occurrences and about $46 \%$ in the weighted scenarios. The mass media system and art follow. Further systems do not (really) count, which now also applies for the legal system that is only present on the front sides of the banknotes.

Finally, we would like to recall that we chose the Euro as research field because its basic concept allows for observing forms of national image cultivation against the background of an international standard. In this sense, we perceive the Euro to be extremely appealing a basis of speculations regarding the relative valence of the function system on both the international and the national levels. Accordingly, a comparison by country tells a lot about national preferences for specific function systems.

Table 4. Final rankings of the function systems (national sides only).

\begin{tabular}{|c|c|c|c|c|c|}
\hline \multicolumn{6}{|c|}{ Share of Function System, National Sides Only (\%) } \\
\hline \multicolumn{2}{|r|}{ Cash Value 'Decisions } & \multicolumn{2}{|r|}{ Weighted Decisions } & \multicolumn{2}{|r|}{ Unweighted Decisions } \\
\hline 1 & $\begin{array}{l}\text { Politics (46.0) } \\
\end{array}$ & 1 & Politics (45.7) & 1 & Politics (38.5) \\
\hline 2 & Mass Media (31.4) & 2 & Mass Media (31.1) & 2 & Mass Media (30.8) \\
\hline 3 & $\operatorname{Art}(16.1)$ & 3 & Art (16.0) & 3 & $\operatorname{Art}(20.4)$ \\
\hline
\end{tabular}




\begin{tabular}{|r|l|r|l|r|l|}
\hline 4 & Economy (3.7) & 4 & Economy (4.3) & 4 & Religion (5.1) \\
\hline 5 & Religion (2.6) & 5 & Religion $(2.6)$ & 5 & Economy (4.6) \\
\hline 6 & Science $(0.3)$ & 6 & Sport $(0.1)$ & 6 & Science $(0.2)$ \\
\hline & Education $(0.3)$ & 7 & Science $(<0.1)$ & & Sport $(0.2)$ \\
\hline & Sport $(0.3)$ & & Education $(<0.1)$ & & Education $(0.2)$ \\
\hline 9 & Legal System $(0.0)$ & 9 & Legal System $(0.0)$ & 9 & Legal System $(0.0)$ \\
\hline & Health $(0.0)$ & & Health $(0.0)$ & & Health $(0.0)$ \\
\hline
\end{tabular}

The top referrer is Greece with a total of 35 references to seven different function systems on its eight national sides (cf. annex, table C3), followed by the Vatican with 32 references and Italy, San Marino as well as Slovenia with 26 references to four systems. On the other side of the scale, we find Estonia and Ireland both referring eight times exclusively to politics. The normal case of function system distribution is something between the continuous triple reference to politics, art, and the mass media system (as represented by the coin sets of France, Luxembourg, Portugal and Slovakia) and the continuous double reference to politics and the mass media system (Belgium, Germany, Monaco and the Netherlands). The mean is 21.1 references to 3.15 systems.

As the last issue has shown, Estonia and Ireland are the most political nations with $100 \%$ of weighted system references devoted to politics (cf. annex, table C2). The highest value for the economics is displayed on the Austrian coins (38.9\%); the highest share of art is in France, Luxemburg, Portugal, and Slovakia (33.3\%); the most religion in Vatican $(25 \%)$ and the Oscar for the mass media goes to Belgium and Germany $(50 \%)$. Only Greece brings the existence of science and education to our minds, even if just proportionally by referring to one of the protagonists of its own era of Enlightenment. The only reference to sport is a pro rata reference of the Italian five Euro coin showing the Coliseum.

Comparing this look through its national windows with the story the entire Euro tells, the most striking finding is a certain discrepancy between the internal and the external communication of the Euro. While the coins, whose usage is mainly limited to 
the Eurozone countries, speak of a considerable dominance of politics, the banknotes present an open-minded Europe. This is true not only with regard to the bridges and windows visually dominating the design, but also in terms of a balanced mix of references to politics, the economy, art, and, maybe rather unnoticed, to the mass media system.

\section{What if science found that it disappeared from most coins and banknotes?}

Looking back through the windows of its national sides, the Euro reappears as an excellent research field for observing forms of national image cultivation against the background of an international standard.

Taking a closer look on what we commonly perceive as money, we initially found that it is not money that carries the famous earmarks (Zelizer 2007), but rather that money itself is an earmark on storage devices for both economic and non-economic data. Reading this data, we needed to re-contextualize the idea of the political 'second mission' of the money: In asking for the function system references of the design elements on the specimens, we found that the greatest number of symbols indeed refers to politics. Unusually, the economy is not the biggest antagonist in the competition for representation on the actually limited space on the Euro coins and banknotes at all. In fact, we found that more symbols minted on the Euro refer to the $\operatorname{art}^{23}$ and to the mass media system than to the economy, which indeed only ranks fourth out of the ten function systems.

Except for health, all function systems of the society appear on at least one coin or banknote of the entire set. What is more, only six symbols did not refer to at least one

\footnotetext{
${ }^{23}$ We focused our analysis on the descriptions of the specimens as provided by the European Central Bank. These descriptions, however, do not point at the fact that all front sides of the Euro coins carry the initials of Luc Luycx, the Belgian designer of the Euro coins. If we had counted this token, art would have outperformed even clearer.
} 
function system. Both facts indicate the plausibility and relevance of the concept of functional differentiation in general and its social systems theoretical version in particular. However, it is still a theoretical and methodological challenge to visualize the invisible function systems. Further research would therefore benefit much from an increasing canonization of the respective terminology.

In any case, our research on the Euro showed a remarkable variety and quantity of function system references beyond those to politics and the economy. We are therefore quite confident that our research will be considered a useful addition to the present 'politico-economic' approaches to the 'monies' of the world. In this sense, future research could also like to take a closer look at reasons for the prevailing preference for analyzing 'monies', 'markets', and even entire societies through the political and the economic lenses (only).

The idea that coins and banknotes are more than money is still a rather contraintuitive thought, even if it is not a completely new one. What is new, however, is the multitude and plurality of function system references that could be shown by our research. Thus, if we broaden our perspective on what we take for our money, then we find plenty starting points for further research that unveils at least as much about "collective identities in a changing Europe" (Schlesinger 1991) as analyses of policy documents, media disseminations, or of Italian or Scottish football (Bradley 1994; Rovati 1992) do. In fact, one of the most rewarding ventures might be to conduct a diachronic iconographic analysis of the European currencies and, by this means, to compare the function system references of the former national currencies with those we found on the Euro. Obviously, the transition from the 'many monies' (Baecker 2003) to the one and only Eurozone currency was accompanied by profound change of the function system preferences. 
If we systematically ask which function systems made it (or did not make it) to the coins and banknotes, then the most striking result of such future research might be the disappearance of science, i.e. a function system that was quiet well represented on national 'monies' like the ones of France or Germany. This finding is quiet a surprise against the background of the current hype of science and innovation rhetoric in Europe. However, this contradiction might indicate that innovation is not perceived as a scientific, but rather as an artistic process. After all, art is ranked third among the function system references on the Euro and therewith outperforms the economy. Hence, by taking the 'European money' as an indicator for the relevance that the individual function systems have for the Eurozone we ironically find that it is not that much about the economy.

\section{References}

Andersen, N. A. 2003. "Polyphonic Organizations.” In Autopoietic Organization Theory, edited by T. Bakken \& T. Hernes, 151-182. Copenhagen: CBS Press.

Baecker, D. 1994. "Soziale Hilfe als Funktionssystem der Gesellschaft." Zeitschrift für Soziologie 23 (2): 93-110.

Baecker, D. 2003. “Geldfunktion und Medienkonkurrenz.” In Viele Gelder, edited by D. Baecker, 12-30. Berlin: Kadmos.

Baecker, D. 2007. "Communication With Computers, or How Next Society Calls for an Understanding of Form.” Soziale Systeme $13(1+2)$ : 45-65.

Bette, K.-H. 1999. Systemtheorie und Sport. Frankfurt am Main: Suhrkamp.

Billig, M. 1995. Banal nationalism. London: Sage.

Boehme, G., and N. Stehr. 1986. The Knowledge society: the growing impact of scientific knowledge on social relations. Dordrecht: D. Reichel Publishing. 
Boustead, E., K. Cottee, R. Farquhar, R. Jonas, J. Walter and P. Webley. 1992. “The Perceived Value of a New Coin.” Journal of Social Psychology 132 (1): 143133.

Boydell, B. 1996. "The Iconography of the Irish Harp as a National Symbol.” Irish Musical Studies. Volume 5. Editedy by P. F. Devine and H. C. White, 131-145. Dublin: Four Courts Press.

Bradley, J. M. 1999. “'Ethnicity': The Irish in Scotland-footbal, politics and identity." Innovation: The European Journal of Social Science Research 7 (4): 423-439.

Cachay, K., and A. Thiel. 2000. Soziologie des Sports: zur Ausdifferenzierung und Entwicklungsdynamik des Sports der modernen Gesellschaft. Weinheim: Juventa

Carruthers, B. G. 2005a. "Money and Society: New Interdisciplinary Perspectives." Sociological Forum 20 (4): 643-649.

Carruthers, B. G. 2005b. “The Sociology of Money and Credit.” In The Handbook of Economic Sociology, edited by N. J. Smelser and R. Swedberg, 355-378. Princeton and Oxford: Princeton University Press.

Carruthers, B. G. 2010. “The Meanings of Money: A Sociological Perspective', Theoretical Inquiries in Law 11 (1): 51-74.

Castells, M. 1996. Rise of The Network Society. Cambridge: Blackwell Publishers.

Cooper, S. 2009. Currency, Identity, and Nation-Building: National Currency Choices in the Post-Soviet States, APSA 2009. Toronto. Accessed July 5. http://ssrn.com/abstract $=1450288$

Croteau, D. and W. Hoynes. 2003. Media Society: Industries, Images and Audiences. Thousand Oaks: Sage. 
de Heij, H. 2010a. "Key Elements in Banknote Design. Part I: The Product

Perspective.” Keesing Journal of Documents and Identity no. 32: 6-12.

de Heij, H. 2010b. “Key Elements in Banknote Design. Part II: The Process

Perspective." Keesing Journal of Documents and Identity no. 33: 14-18.

de Heij, H. and E. van den Kommer 2008. The Roles of De Nederlandsche Bank in Euro

Banknote Circulation. Amsterdam: De Nederlandsche Bank. Accessed July 5.

http://www.dnb.nl/en/binaries/Roles\%20of\%20DNB_tcm47-185440.pdf

Dennis, E. E. 1978. The media society: evidence about mass communication in

America. Dubuque: W. C. Brown.

Drucker, P. F. 2002. Managing in the Next Society. New York: Truman Talley Books.

Eaman, R. A. 1987. The media society: basic issues and controversies. London:

Butterworths.

EC. 2000. Euro Coins. From Design to Circulation, Euro Papers (Vol. 37). Bruxelles:

European Commission. Accessed July 5.

http://ec.europa.eu/economy_finance/publications/publication1077_en.pdf

ECB. (2010a). Euro Banknotes. Frankfurt am Main: European Central Bank. Accessed

July 5. http://www.ecb.int/euro/banknotes/html/index.en.html

ECB. 2010b. Euro Coins. Frankfurt am Main: European Central Bank. Accessed July 5.

http://www.ecb.int/euro/coins/html/index.en.html

ECB. 2011a. How the euro became our money. A short history of the euro banknotes and coins. Frankfurt am Main: European Central Bank. Accessed July 5. http://www.ecb.int/pub/pdf/other/euro_became_our_moneyen.pdf

ECB. 2011b. Publications. Frankfurt am Main: European Central Bank. Accessed July

5. http://www.ecb.int/pub/html/index.en.html 
Esposito, E. 2006. "Was man von den unsichtbaren Medien sehen kann.” Soziale Systeme 12 (1): 54-78.

Fornäs, J. 2008. "Meanings of Money: The Euro as a Sign of Value and of Cultural Identity." In We Europeans? Media, Representations, Identities, edited by W. Uricchio, 123-139. Bristol: Intellect.

Foucault, M. 1970. The Order of Things: An Archaeology of The Human Sciences. London: Tavistock.

Fuchs, P. 2000. “Systemtheorie und Soziale Arbeit” In Systemtheorie Sozialer Arbeit. Neue Ansätze und veränderte Perspektiven, edited by R. Merten, 157-175 Opladen: Leske und Budrich.

Götze, H. 1998. Castel del Monte: geometric marvel of the Middle Ages. London: Prestel Publishing.

Hymans, J. E. C. 2004. “The Changing Color of Money: European Currency Iconography and Collective Identity." European Journal of International Relations 10 (1): 5-31.

Ivic, S. and D. D. Lakicevic. 2011. "European identity: between modernity and postmodernity." Innovation: The European Journal of Social Science Research 24 (4): 395-407.

Ingham, G. 2001. "Fundamentals of a theory of money: untangling Fine, Lapavitsas and Zelizer." Economy and Society 30 (3): 304 - 323.

Ingham, G. 2007. “The Specificity of Money.” European Journal of Sociology 48 (2): $265-272$.

Jones, C. and E. Surman. 2002. “After Organization Studies.” Ephemera. Critical Dialogues on Organization 2 (3): 186-192. 
Künzler, J. 1987. “Grundlagenprobleme der Theorie symbolisch generalisierter Kommunikationsmedien bei Niklas Luhmann.” Zeitschrift für Soziologie 16 (5): 317-333.

Künzler, J. 1989. Medien und Gesellschaft. Die Medienkonzepte von Talcott Parsons, Jürgen Habermas und Niklas Luhmann. Stuttgart: Enke.

Lapavitsas, C. 2005. “The Social Relations of Money as Universal Equivalent: A Response to Ingham.” Economy and Society 34 (3): 389-403.

Lauer, J. 2008. "Money as Mass Communication: U.S. Paper Currency and the Iconography of Nationalism.” The Communication Review 11 (2): 109-132. Luhmann N. (1977) Differentiation of Society. The Canadian Journal of Sociology / Cahiers canadiens de sociologie 2 (1): 29-53.

Luhmann, N. 1979. Die Religion der Gesellschaft. Frankfurt am Main: Suhrkamp. Luhmann, N. 1984. Soziale Systeme. Frankfurt am Main: Suhrkamp. Luhmann, N. 1988. Die Wirtschaft der Gesellschaft. Frankfurt am Main: Suhrkamp. Luhmann, N. 1990a. “Der medizinische Code.”. In Soziologische Aufklärung 5: Konstruktivistische Perspektiven, edited by N. Luhmann, 183-195. Opladen: Westdeutscher Verlag.

Luhmann, N. 1990b. Die Wissenschaft der Gesellschaft. Frankfurt am Main: Suhrkamp. Luhmann, N. 1995a. Das Recht der Gesellschaft. Frankfurt am Main: Suhrkamp. Luhmann, N. 1995b. Die Kunst der Gesellschaft. Frankfurt am Main: Suhrkamp. Luhmann, N. 1995c. Social Systems. Stanford: Standford University Press. Luhmann, N. 1996. Die Realität der Massenmedien. Opladen: Westdeutscher Verlag. Luhmann, N. 1997. Die Gesellschaft der Gesellschaft. Band 1 und 2. Frankfurt am Main: Suhrkamp. 
Luhmann, N. 2000a. Art as a Social System. Palo Alto: Stanford University Press.

Luhmann, N. 2000b. Die Politik der Gesellschaft. Frankfurt am Main: Suhrkamp.

Luhmann, N. 2000c. The Reality of the Mass Media. Palo Alto: Stanford University Press.

Luhmann, N. 2001. Das Erziehungssystem der Gesellschaft. Frankfurt am Main: Suhrkamp.

Luhmann, N. 2008. Law as a Social System. Oxford: Oxford University Press.

Luhmann N and Barrett R. (2012) Theory of Society. Palo Alto: Stanford University Press.

Maass, O. 2009. Die Soziale Arbeit als Funktionssystem der Gesellschaft. Heidelberg: Carl Auer.

Marian-Bälasa, M. 2003. "Music on money: State legitimation and cultural representation." Music in Art: International Journal for Music Iconography 28 (1-2): 173-189.

Marazzi, C. 2004. “Who Killed God Pan?” Ephemera. Critical Dialogues on Organization 4 (3): 181-186.

Nemes, C. N. 2002. “Anaesthesia in nummis.” International Congress Series no. 1242: $521-529$.

Papadopoulos, G. 2009. "Between Rules and Power: Money as an Institution Sanctioned by Political Authority" Journal of Economic Issues 43 (4): 951-969.

Priddat, B. P. 2003. “Rätsel Geld: Anderes Geld.” In Viele Gelder, edited by D. Baecker, 120-148. Berlin: Kulturverlag Kadmos.

Poche, B. 1997. “L’identité collective, mode sensible d'appréhension du monde.” Innovation: The European Journal of Social Science Research 10 (4): 419-431. 
Raento, P., A. Hämäläinen, H. Ikonen, and N. Mikkonen. 2004. "Striking stories: a political geography of euro coinage" Political Geography 23 (8): 929-956.

Reese-Schäfer, W. 1999. Luhmann zur Einführung. Hamburg: Junius.

Reese-Schäfer, W. 2007. Politisches Denken heute : Zivilgesellschaft, Globalisierung und Menschenrechte. München: Oldenbourg.

Risse, T. 2003. "The Euro between national and European identity." Journal of European Public Policy 10 (4): 487-505.

Rovati, G. 1992. "Political localism and national identity in Italy: The case of regional leagues." Innovation: The European Journal of Social Science Research 5 (2): 69-76.

Schlesinger, P. 1991. "Collective identities in a changing Europe." Innovation: The European Journal of Social Science Research 4 (1): 41-63.

Schlesinger, P. 1999. “Collective identities, friends, enemies.” Innovation: The European Journal of Social Science Research 12 (4): 461-469.

Shell, M. 1995. Art and money. Chicago and London: University of Chicago Press.

Stichweh, R. 1995. "Zur Theorie der Weltgesellschaft.” Soziale Systeme 1 (1): 29-45.

Vorreiter, L. 1975. "Music history from images on coins.” Musica 29 (2): 117-121.

Wallerstein, I. 2003. Decline of American Power: The U.S. in a Chaotic World. New York: New Press.

Warren, S. 2002. “'Show Me How it Feels to Work Here': Using Photography to Research Organizational Aesthetics.” Ephemera. Critical Dialogues on Organization 2 (3): 224-245.

Wasserstein, D. J. 1993. "Coins as Agents of Cultural Definition in Islam.” Poetics Today. Special Issue on Cultural Processes in Muslim and Arab Societies: Medieval and Early Modern Periods 14 (2): 303-322. 
Zäch, B. (2005). 'Images of the Euro: National representation and European identity', pp. 1429-1433 in C. Alfaro, C. Marcos \& P. Otero (eds), XIII Congreso Internacional de Numismática: Actas, Proceedings, Actes, Vol. II. Madrid: Ministerio de Cultura.

Zakaria, F. (1999). Money for Mars, Newsweek (Vol. 11. January).

Zelizer, V. (1997). The Social Meaning of Money. Princeton: Princeton University Press. 


\section{Appendix}

Tables A. Function System Reference of Common Features of the Common

\section{Currency}

Table A1. Euro Banknotes ${ }^{24}$

\begin{tabular}{|c|c|c|c|}
\hline Value & Description & Function System & FS Codes \\
\hline & $\begin{array}{l}\text { General features: "Euro banknotes }(. . .) \text { feature } \\
\text { architectural styles from different periods in } \\
\text { Europe's history" }\end{array}$ & & \\
\hline$€ 500$ & $\begin{array}{l}\text { Front: "On the front, the banknotes show windows } \\
\text { and gateways. They symbolise the European spirit } \\
\text { of openness and cooperation. The } 12 \text { stars of the } \\
\text { European Union (EU) represent the dynamism and } \\
\text { harmony of contemporary Europe" } \\
\text { Additional feature: Note value, copyright symbol, } \\
\text { and initials of the ECB. }\end{array}$ & $\begin{array}{l}\text { Politics, Economy, Art, } \\
\text { Legal System }^{25} \text {, Mass } \\
\text { Media }^{26}\end{array}$ & $\begin{array}{l}1,2,4,6, \\
10\end{array}$ \\
\hline$€ 500$ & $\begin{array}{l}\text { Back: "The bridges on the back symbolise } \\
\text { communication between the people of Europe and } \\
\text { between Europe and the rest of the world" } \\
\text { "The central bank that commissioned the printing } \\
\text { of a banknote (but not necessarily the country of } \\
\text { printing) is indicated by a letter or country code } \\
\text { preceding the serial number" } \\
\text { "The banknotes show a geographical representation } \\
\text { of Europe. It excludes islands of less than } 400 \\
\text { square kilometres because high-volume offset } \\
\text { printing does not permit the accurate reproduction } \\
\text { of small design elements" } \\
\text { Additional feature: Note value. }\end{array}$ & $\begin{array}{l}\text { Politics, Economy, Art, } \\
\text { Mass Media }\end{array}$ & $1,2,4,10$ \\
\hline
\end{tabular}

Table A2. Common Sides of Euro Coins ${ }^{27,28}$

\begin{tabular}{|l|l|l|l|}
\hline Value & Description & Function System & FS Codes \\
\hline$€ 2$ & $\begin{array}{l}\text { These coins "show either the European Union } \\
\text { before its enlargement on 1 May 2004 or, as of 1 } \\
\text { January 2007, a geographical image of Europe. } \\
\text { Coins from Italy (including San Marino and the } \\
\text { Vatican City), Austria and Portugal show the more }\end{array}$ & Politics, Economy & 1,2 \\
\hline
\end{tabular}

${ }^{24}$ All quotations taken from the European Central Bank (ECB 2010a) unless otherwise noted.

${ }^{25}$ The copyright symbol indicates a reference to the legal system.

${ }^{26}$ The motif of printing is clearly present in the description as well as in terms of serial numbers and the initials of the ECB "that commissioned the printing of a banknote".

${ }^{27}$ All quotations taken from the European Central Bank (ECB 2010b) unless otherwise noted.

${ }^{28}$ The edge is the second common side of the three sides of the Euro coins. Except for the $2 €$ coins, it is free of reference to any functional system; rather, it is main function is oriented to persons with impaired sight. This concession to the health system, however, is only formal. In terms of content, there is the economy on the edge. 


\begin{tabular}{|l|l|l|l|}
\hline$€ 0.1$ & $\begin{array}{l}\text { recent design only if they are dated '2008' or later" } \\
\text { Additional feature: Coin value. }\end{array}$ & \\
\hline$€ 0.05$ & $\begin{array}{l}\text { These coins “show Europe in relation to Africa and } \\
\text { Asia on a globe” }\end{array}$ & Politics, Economy & 1,2 \\
$€ 0.01$ & \begin{tabular}{l} 
Additional feature: Coin value. \\
\hline
\end{tabular}
\end{tabular}

Tables B. Function System Reference of the National Sides of Euro Coins

Available online.

Tables C. The distribution of decisions for function system references on the national sides of the Euro coins

Tables $\mathrm{C} 1$ and $\mathrm{C} 3$ available online

Table C2. The distribution of decisions for function system references on the national sides of the Euro coins, weighted in terms of the combined coin rank and coin share.

\begin{tabular}{|c|c|c|c|c|c|c|c|c|c|c|c|c|}
\hline & & & are 0 & Decisio & per $F$ & netio & A Sys & $\mathrm{em}(\mathrm{w}$ & ightec & & & \\
\hline & pol & eco & sci & art & rel & leg & hea & spo & edu & mme & non & $\sum$ \\
\hline Austria & 14.00 & 14.00 & 0 & 7.00 & 1.00 & 0 & 0 & 0 & 0 & 0 & 0 & 36 \\
\hline$\%$ & 38.89 & 38.89 & 0 & 19.44 & 2.78 & 0 & 0 & 0 & 0 & 0 & 0 & 100 \\
\hline Belgium & 18.00 & 0 & 0 & 0 & 0 & 0 & 0 & 0 & 0 & 18.00 & 0 & 36 \\
\hline$\%$ & 50 & 0 & 0 & 0 & 0 & 0 & 0 & 0 & 0 & 50 & 0 & 100 \\
\hline Cyprus & 18.00 & 7.50 & 0 & 7.50 & 0 & 0 & 0 & 0 & 0 & 0 & 3.00 & 36 \\
\hline$\%$ & 50 & 20.83 & 0 & 20.83 & 0 & 0 & 0 & 0 & 0 & 0 & 8.33 & 100 \\
\hline Estonia & 36.00 & 0 & 0 & 0 & 0 & 0 & 0 & 0 & 0 & 0 & 0 & 36 \\
\hline$\%$ & 100 & 0 & 0 & 0 & 0 & 0 & 0 & 0 & 0 & 0 & 0 & 100 \\
\hline Finland & 16.67 & 0 & 0 & 0 & 0 & 0 & 0 & 0 & 0 & 16.67 & 2.67 & 36 \\
\hline$\%$ & 46.30 & 0 & 0 & 0 & 0 & 0 & 0 & 0 & 0 & 46.30 & 7.41 & 100 \\
\hline France & 12.00 & 0 & 0 & 12.00 & 0 & 0 & 0 & 0 & 0 & 12.00 & 0 & 36 \\
\hline$\%$ & 33.33 & 0 & 0 & 33.33 & 0 & 0 & 0 & 0 & 0 & 33.33 & 0 & 100 \\
\hline Germany & 18.00 & 0 & 0 & 0 & 0 & 0 & 0 & 0 & 0 & 18.00 & 0 & 36 \\
\hline$\%$ & 50 & 0 & 0 & 0 & 0 & 0 & 0 & 0 & 0 & 50 & 0 & 100 \\
\hline Greece & 8.27 & 8.27 & 0.67 & 8.27 & 1.60 & 0 & 0 & 0 & 0.67 & 8.27 & 0 & 36 \\
\hline$\%$ & 22.96 & 22.96 & 1.85 & 22.96 & 4.44 & 0 & 0 & 0 & 1.85 & 22.96 & 0 & 100 \\
\hline Ireland & 36.00 & 0 & 0 & 0 & 0 & 0 & 0 & 0 & 0 & 0 & 0 & 36 \\
\hline$\%$ & 100 & 0 & 0 & 0 & 0 & 0 & 0 & 0 & 0 & 0 & 0 & 100 \\
\hline Italy & 11.67 & 0 & 0 & 11.67 & 0 & 0 & 0 & 0.75 & 0 & 11.67 & 0.25 & 36 \\
\hline$\%$ & 32.41 & 0 & 0 & 32.41 & 0 & 0 & 0 & 2.08 & 0 & 32.41 & 0.69 & 100 \\
\hline Luxembourg & 12.00 & 0 & 0 & 12.00 & 0 & 0 & 0 & 0 & 0 & 12.00 & 0 & 36 \\
\hline$\%$ & 33.33 & 0 & 0 & 33.33 & 0 & 0 & 0 & 0 & 0 & 33.33 & 0 & 100 \\
\hline Malta & 16.50 & 0 & 0 & 1.50 & 1.50 & 0 & 0 & 0 & 0 & 16.50 & 0 & 36 \\
\hline
\end{tabular}




\begin{tabular}{|l|ccccccccccc|c|}
\cline { 2 - 5 } & 45.83 & 0 & 0 & 4.17 & 4.17 & 0 & 0 & 0 & 0 & 45.83 & 0 & 100 \\
Monaco & 18.00 & 0 & 0 & 0 & 0 & 0 & 0 & 0 & 0 & 18.00 & 0 & 36 \\
$\%$ & 50 & 0 & 0 & 0 & 0 & 0 & 0 & 0 & 0 & 50 & 0 & 100 \\
Netherlands & 18.00 & 0 & 0 & 0 & 0 & 0 & 0 & 0 & 0 & 18.00 & 0 & 36 \\
$\%$ & 50 & 0 & 0 & 0 & 0 & 0 & 0 & 0 & 0 & 50 & 0 & 100 \\
Portugal & 12.00 & 0 & 0 & 12.00 & 0 & 0 & 0 & 0 & 0 & 12.00 & 0 & 36 \\
$\%$ & 33.33 & 0 & 0 & 33.33 & 0 & 0 & 0 & 0 & 0 & 33.33 & 0 & 100 \\
San Marino & 11.25 & 0 & 0 & 11.25 & 2.25 & 0 & 0 & 0 & 0 & 11.25 & 0 & 36 \\
$\%$ & 31.25 & 0 & 0 & 31.25 & 6.25 & 0 & 0 & 0 & 0 & 31.25 & 0 & 100 \\
Slovakia & 12.00 & 0 & 0 & 12.00 & 0 & 0 & 0 & 0 & 0 & 12.00 & 0 & 36 \\
$\%$ & 33.33 & 0 & 0 & 33.33 & 0 & 0 & 0 & 0 & 0 & 33.33 & 0 & 100 \\
Slovenia & 14.67 & 1.00 & 0 & 3.33 & 2.00 & 0 & 0 & 0 & 0 & 14.67 & 0.33 & 36 \\
$\%$ & 40.75 & 2.78 & 0 & 9.26 & 5.56 & 0 & 0 & 0 & 0 & 40.75 & 0.93 & 100 \\
Spain & 14.00 & 0 & 0 & 6.50 & 1.50 & 0 & 0 & 0 & 0 & 14.00 & 0 & 36 \\
$\%$ & 38.89 & 0 & 0 & 18.06 & 4.17 & 0 & 0 & 0 & 0 & 38.89 & 0 & 100 \\
Vatican & 9.00 & 0 & 0 & 9.00 & 9.00 & 0 & 0 & 0 & 0 & 9.00 & 0 & 36 \\
$\%$ & 25.00 & 0 & 0 & 25.00 & 25.00 & 0 & 0 & 0 & 0 & 25.00 & 0 & 100 \\
\hline Point Value & $\mathbf{3 2 6 . 0 2}$ & $\mathbf{3 0 . 7 7}$ & $\mathbf{0 . 6 7}$ & $\mathbf{1 1 4 . 0 2}$ & $\mathbf{1 8 . 8 5}$ & $\mathbf{0}$ & $\mathbf{0}$ & $\mathbf{0 . 7 5}$ & $\mathbf{0 . 6 7}$ & $\mathbf{2 2 2 . 0 2}$ & $\mathbf{6 . 2 5}$ & $\mathbf{7 2 0}$ \\
$\%$ & 45.28 & 4.27 & 0.09 & 15.84 & 2.62 & 0 & 0 & 0.10 & 0.09 & 30.84 & 0.87 & 100 \\
$\%$ FS & 45.68 & 4.31 & 0.09 & 15.97 & 2.64 & 0 & 0 & 0.11 & 0.09 & 31.11 & 0 & 100 \\
\hline Rank FS & $\mathbf{1}$ & $\mathbf{4}$ & $\mathbf{7}$ & $\mathbf{3}$ & $\mathbf{5}$ & $\mathbf{9}$ & $\mathbf{9}$ & $\mathbf{6}$ & $\mathbf{7}$ & $\mathbf{2}$ & $\mathbf{0}$ & $\mathbf{1 0}$ \\
\hline
\end{tabular}

\section{Tables R: The distribution of decisions for function system references on the Euro}

Tables R1 and R3 available online.

Table R2. The distribution of decisions for function system references on the Euro, weighted in terms of the combined coin rank and coin share.

\begin{tabular}{|c|c|c|c|c|c|c|c|c|c|c|c|c|}
\hline & & & hare & f Decisio & Is per $F$ & Inctio & Syst & n (we & shted) & & & \\
\hline & pol & eco & sci & art & rel & leg & hea & spo & edu & mme & non & $\Sigma$ \\
\hline CoinNS & 326.02 & 30.77 & 0.67 & 114.02 & 18.85 & 0 & 0 & 0.75 & 0.67 & 222.02 & 6.25 & 720 \\
\hline$\%$ Side & 45.28 & 4.27 & 0.09 & 15.84 & 2.62 & 0 & 0 & 0.10 & 0.09 & 30.84 & 0.87 & 100 \\
\hline$\%$ Coin & 58.18 & 6.51 & 0.11 & 5.01 & 3.31 & 0 & 0 & 0.11 & 0.11 & 21.06 & 0.86 & 95.2 \\
\hline CoinCS & 18 & 18 & 0 & 0 & 0 & 0 & 0 & 0 & 0 & 0 & 0 & 36 \\
\hline$\%$ Side & 50 & 50 & 0 & 0 & 0 & 0 & 0 & 0 & 0 & 0 & 0 & 100 \\
\hline$\%$ Coin & 2.39 & 2.39 & 0 & 0 & 0 & 0 & 0 & 0 & 0 & 0 & 0 & 4.8 \\
\hline Coin & 344.02 & 48.77 & 0.67 & 114.02 & 18.85 & 0 & $\mathbf{0}$ & 0.75 & 0.67 & 222.02 & 6.25 & 756 \\
\hline$\%$ Coin & 45.50 & 6.45 & 0.09 & 15.08 & 2.49 & 0 & 0 & 0.10 & 0.09 & 29.37 & 0.83 & 100 \\
\hline NoteFront & 8.4 & 8.4 & 0 & 8.4 & 0 & 8.4 & 0 & 0 & 0 & 8.4 & 0 & 42 \\
\hline$\%$ Side & 20 & 0 & 0 & 20 & 0 & 20 & 0 & 0 & 0 & 20 & 0 & 100 \\
\hline$\%$ Note & 10 & 0 & 0 & 10 & 0 & 10 & 0 & 0 & 0 & 10 & 0 & 50 \\
\hline NoteBack & 10.5 & 10.5 & 0 & 10.5 & 0 & 0 & 0 & 0 & 0 & 10.5 & 0 & 42 \\
\hline$\%$ Side & 25 & 25 & 0 & 25 & 0 & 0 & 0 & 0 & 0 & 25 & 0 & 100 \\
\hline
\end{tabular}




\begin{tabular}{|l|ccccccccccc|c|} 
\% Note & 12.5 & 12.5 & 0 & 12.5 & 0 & 0 & 0 & 0 & 0 & 12.5 & 0 & 50 \\
\hline Note & $\mathbf{1 8 . 9}$ & $\mathbf{1 8 . 9}$ & $\mathbf{0}$ & $\mathbf{1 8 . 9}$ & $\mathbf{0}$ & $\mathbf{8 . 4}$ & $\mathbf{0}$ & $\mathbf{0}$ & $\mathbf{0}$ & $\mathbf{1 8 . 9}$ & $\mathbf{0}$ & $\mathbf{8 4}$ \\
\% Note & 50 & 0 & 0 & 50 & 0 & 0 & 0 & 0 & 0 & 0 & 0 & 100 \\
\hline Currency & $\mathbf{3 6 2 . 9 2}$ & $\mathbf{6 7 . 6 7}$ & $\mathbf{0 . 6 7}$ & $\mathbf{1 3 2 . 9 2}$ & $\mathbf{1 8 . 8 5}$ & $\mathbf{8 . 4 0}$ & $\mathbf{0}$ & $\mathbf{0 . 7 5}$ & $\mathbf{0 . 6 7}$ & $\mathbf{2 4 0 . 9 2}$ & $\mathbf{6 . 2 5}$ & $\mathbf{8 4 0}$ \\
\% Curr & 43.21 & 8.06 & 0.08 & 15.82 & 2.24 & 1.00 & 0.00 & 0.09 & 0.08 & 28.68 & 0.74 & 100 \\
$\%$ FS & 43.52 & 8.12 & 0.08 & 15.94 & 2.26 & 1.01 & 0.00 & 0.09 & 0.08 & 28.90 & 0.00 & 833.8 \\
\hline Rank FS & $\mathbf{1}$ & $\mathbf{4}$ & $\mathbf{8}$ & $\mathbf{3}$ & $\mathbf{5}$ & $\mathbf{6}$ & $\mathbf{1 0}$ & $\mathbf{7}$ & $\mathbf{8}$ & $\mathbf{2}$ & $\mathbf{0}$ & $\mathbf{1 0}$ \\
\hline
\end{tabular}

